\title{
PENGARUH ARTIFICIAL RECHARGE MELALUI LOBANG RESAP BIOPORI TERHADAP MUKA AIR TANAH
}

\author{
Oleh: Pungut *) dan Sri Widyastuti**)
}

\begin{abstract}
Abstrak
Berubahnya tata guna lahan dari areal terbuka yang permukaannya ditutupi oleh vegetasi menjadi areal terbangun yang permukaan tanahnya dilapisi oleh penutup kedap air seperti atap bangunan, perkerasan jalan aspal maupun pemasangan lapisan beton menjadikan volume air limpasan hujan sangat sedikit yang meresap ke dalam lapisan tanah. Oleh karena itu maka keberadaan air tanah menjadi sangat berkurang volume cadangannya. Hal ini berlangsung secara meningkat sehingga level muka air tanah semakin dalam dari muka tanah. Dalam kondisi seperti itu diperlukan metode penggantian proses infiltrasi air limpasan hujan ke dalam lapisan tanah. Beberapa metode imbuhan buatan (artificial recharge) telah diterapkan dibeberapa tempat seperti metode danau buatan, kolam resapan, parit resap, dan sumur resapan. Maka lubang resap biopori perlu dikaji keandalannya di dalam membantu proses infiltrasi air limpasan hujan sehingga berdampak terhadap deposit air tanah.

Dalam penelitian ini penerapan biopori pada seluasan areal telah terbukti memiliki peran yang cukup signifikan, bahwa biopori juga mampu meresapkan air ke dalam tanah. Indikasi dari manfaat biopori ini dapat dilihat adanya perbedaan ketinggian muka air tanah pada areal yang diberi terapan biopori dibandingkan pada areal yang tidak diberi terapan biopori. Selain itu, kecepatan pertambahan level muka air tanah juga terlihat secara nyata bahwa pada areal biopori lebih cepat.
\end{abstract}

Kata Kunci: air limpasan hujan, infiltrasi, lobang resap biopori, muka airtanah.

\section{PENDAHULUAN}

\section{A. Latar Belakang Masalah.}

Pembangunan di kawasan baru, satu sisi merupakan solusi dari kebutuhan yang dari waktu ke waktu selalu meningkat, akan tetapi dengan pembukaan kawasan baru maka tidak dapat dihindarkan adanya perubahan tataguna lahan. Lahan yang semula terbuka, kemudian diperuntukan bagi keperluan bangunan dan fasilitas lain yang dibangun secara memberi lapisan perkerasan pada lahan ataupun menutupnya dengan atap. Pada perkembangan selanjutnya, lahan yang terbuka pun sudah diberi lapisan perkerasan yang bersifat tidak tembus air. Hal demikian berarti tidak ada kesempatan bagi air untuk meresap ke dalam tanah. Akibat dari keadaan ini, air hujan sedikit yang terinfiltrasi dan selebihnya menjadi limpasan permukaan. Dengan demikian banjir yang berupa genangan mudah terjadi karena air hujan secara cepat menjadi limpasan permukaan. Jadi berubahnya tataguna lahan dari lahan terbuka menjadi lahan yang kedap mengakibatkan bertambahnya volume air yang harus dialirkan pada kawasan itu.

$$
\text { Upaya untuk mengatasi }
$$

permasalahan air limpasan hujan yang sering dilakukan ialah pembenahan sistem jaringan drainase. Selain itu, biasanya juga menambah besar dimensi saluran, serta pengerukan endapan lumpur pada dasar saluran. Namun hal itu mungkin bukan merupakan penyelesaian akhir sebagaimana yang diharapkan. Selain upaya mengatasi banjir dengan jalan memperbaiki jaringan dan fisik saluran drainase, perlu diadakan tindakan lain yang dipandang memiliki peranan yang berarti.

Jarang sekali dipikirkan bahwa keberadaan air limpasan permukaan akibat hujan tersebut sesungguhnya sangat diperlukan untuk menambah deposit air dalam tanah. Oleh karena itu, sebenarnya menanggulangi permasalahan genangan air hujan seharusnya tidak hanya ditanggulangi dampaknya pada sistem drainase permukaan, akan tetapi harus dipikirkan pula bagaimana meresapkan air hujan itu ke dalam lapisan tanah.

Memperhatikan uraian tersebut, dipandang perlu mengadakan upaya lain selain mengatasi fisik dan jaringan saluran drainase. Bentuk upaya yang diharapkan memiliki andil cukup besar dalam mengatasi masalah air limpasan hujan ini ialah partisipasi warga dalam bentuk meresapkan air hujan itu ke dalam tanah. Salah satu metode peresapan air ke dalam lapisan tanah itu adalah menggunakan metode lobang resap biopori.

\footnotetext{
*) Dosen Teknik Lingkungan

**) Dosen Teknik Lingkungan

Universitas PGRI Adi Buana Surabaya
} 
Lubang resap biopori dibuat untuk menangkap air limpasan permukaan agar meresap ke dalam tanah melalui kemampuan filtrasi tanah. Jadi, biopori selain berfungsi sebagai wadah untuk menampung air hujan, juga berfungsi sebagai media agar air mengalami proses resap ke dalam tanah. Dengan demikian peranannya adalah memperkecil debit limpasan permukaan langsung (direct runoff), sehingga diharapkan tidak terjadi genangan di atas permukaan tanah.

Salah satu aspek kinerja lobang resap biopori adalah aspek kemanfaatannya di dalam menjamin adanya imbuhan buatan terhadap air tanah (groundwater). Sebab salah satu dampak dari berubahnya tata guna lahan dari lahan terbuka menjadi lahan yang terbangun dengan menutup permukaan tanah tersebut adalah terhentinya proses suplai terhadap air tanah melalui proses infiltrasi dan perkolasi. Dalam hal ini, jika proses imbuhan airtanah secara alami terhenti, maka proses imbuhan air tanah secara buatan (artificial recharge) adalah penggantinya. Biopori adalah salah satu metode peresapan buatan.

Indikasi bahwa biopori mampu melakukan peresapan air hujan ke dalam lapisan tanah adalah adanya kenaikan muka air tanah (water table) pada air tanah di bawah lokasi yang dipasang biopori. Seberapa signifikan kecepatan imbuhan buatan oleh biopori terhadap keberadaan air tanah, dapat ditinjau perbedaan level muka air tanah pada kondisi yang bersamaan antara kawasan yang diberi lobang resap biopori dan kawasan yang tidak dipasang lobang resap biopori.

\section{B. Batasan Masalah.}

Lubang resap biopori adalah pipa PVC berdiameter 4 inchi, dinding sampingnya diberi lubang-lubang peresapan dengan panjang pipa tertanam dalam tanah $=100 \mathrm{~cm}$.

1. Jarak pasang yang diterapkan $=200$ $\mathrm{cm}$ ke arah sumbu $X$ dansumbu $Y$.

2. Luas kawasan yang dipasang $8 \mathrm{mx}$ $8 \mathrm{~m}$ atau terpasang 5 biopori $\times 5$ biopori = 25 lobang resap biopori.

3. Waktu pengamatan antara kejadian hujan dengan pengukuran muka air tanah antara $10 \mathrm{~s} / \mathrm{d} 15 \mathrm{jam}$.
4. Lubang resap biopori diisi sampah daun, akan tetapi tidak dikaji pengaruhnya dalam studi ini.

5. Lapisan tanah pada biopori diasumsikan sebagai akuifer bebas (unconfined aquifer), sebab merupakan hasil timbunan dari material yang homogeny jenis sirtu (pasir-batu).

6. Lubang resap biopori memiliki bidang resap pada bagian dinding yang berupa lubang-lubang pada dinding pipa, dan pada dasar.

\section{Rumusan Masalah.}

1. Apakah terdapat perbedaan kecepatan kenaikan muka air tanah (water table) antara areal yang dipasang lobang resap biopori dengan areal yang tidak dipasang lobang resap biopori.

2. Berapa persen perbedaan kecepatan kenaikan muka airtanah (water table) antara areal yang dipasang lobang resap biopori dengan areal yang tidak dipasang lobang resap biopori, terhadap kondisi muka air tanah asli sebelumnya (steady).

\section{Tujuan dan Manfaat Penelitian.}

\section{Tujuan Penelitian.}

a. Untuk mengetahui keberadaan muka air tanah di areal studi pada kondisi steady pada saat dilaksanakan studi.

b. Untuk mengetahui adanya kenaikan muka air tanah di areal studi akibat adanya infiltrasi air hujan secara alami dan secara rekayasa.

c. Untuk mengetahui perbeaan kecepatan kenaikan muka air tanah (water table) antara areal yang dipasang lubang resap biopori dengan areal yang tidak dipasang lubang resap biopori.

d. Untuk mengetahui nilai perbedaan kecepatan kenaikan muka air tanah (water table) antara areal yang dipasang lubang resap biopori dengan areal yang tidak dipasang lubang resap biopori, terhadap 
kondisi muka air tanah asli sebelumnya (steady).

\section{Manfaat Penelitian.}

a. Sebagai acuan praktis pada penerapan pembuatan biopori.

b. Dapat digunakan sebagai bahan pertimbangan dalam memilih metode penerapan biopori sesuai keadaan tanah setempat, medan penerapan setempat dan kemampuan teknologi serta beaya yang ada.

c. Dapat digunakan sebagai rekomendasi untuk menetapkan jarak antar biopori, karena telah diketahui dampaknya terhadap kenaikan muka air tanah pada kondisi studi ini.

d. Dapat digunakan sebagai bahan rekomendasi guna mengetahui dimensi biopori ditinjau dari keefektifan kemampuan resapnya.

\section{KAJIAN PUSTAKA}

\section{A. Unsur-unsur Peresapan Air ke Dalam Lapisan Tanah}

\section{Air Limpasan Hujan}

Air limpasan hujan yang mengalir akan meresap masuk ke dalam tanah, tiap satuan waktu. Apabila lobang resap biopori dimaksudkan sebagai sarana drainase limpasan permukaan akibat hujan, maka volume air limpasan sebagai debit masukan Qi adalah debit limpasan permukaan dari suatu luasan tertentu. Jika media lobang resap biopori itu adalah sarana drainase bangunan tempat tinggal, maka debit masukan Qi adalah berupa debit air yang terkumpul dari permukaan penutup atap.

Besarnya debit masukan dapat ditentukan dengan perencanaan empiris berdasarkan data hujan yang direkam. Meskipun kenyataannya besarnya debit dari awal hujan sampai akhir hujan adalah tidak tetap, akan tetapi dapat diambil nilai dominan sebagai pedoman perencanaan. Besarnya debit masukan ini sangat tergantung pada intensitas hujan yang terjadi dan luasan yang hendak didrain. Intensitas hujan bergantung pada tinggi curah hujan dan durasinya, sedangkan permukaan penangkap hujan dipengaruhi oleh luas dan koefisien pengalirannya.

Penentuan besarnya debit masukan Qi secara empiris yang bersifat praktis untuk luasan yang relatif kecil sebagaimana lahan hunian adalah menggunakan metode Rasional. Dalam hal ini Soemarto (2000) mendefinisikan :

$Q=\operatorname{ci} A$

yang mana

$Q=$ debit dalam $m^{3} / \mathrm{dt}$.

$c=$ koefisien pengaliran permukaan, yang besarnya $<1$.

$i=$ intensitas hujan.

$A=$ luas bidang tangkapan hujan.

Luasan bidang tangkapan hujan untuk bangunan tempat tinggal adalah berupa luas atap yang diukur secara horizontal. Untuk intensitas hujan $i$ apabila tidak mengadakan pengukuran langsung di lapangan maka perlu menghitung secara empiris. Metode empiris yang dapat dipilih misalnya menggunakan formulasi Mononobe dalam Soemarto (2000), yaitu :

$$
i=\frac{d_{24}}{24} \cdot\left(\frac{24}{t}\right)^{2 / 3}
$$

dalam hal ini

$i=$ intensitas hujan $(\mathrm{mm} / \mathrm{jam})$.

$d_{24}=$ tinggi hujan dalam 24 jam (mm).

$t=$ durasi hujan dominan ( jam ).

Untuk koefisien pengaliran $c$, apabila tidak diukur langsung pada medan pengaliran yang dimaksud, maka dapat digunakan perkiraan nilai koefisien c secara empiris berdasarkan hasil penelitian. Dalam hal ini Shi Yui Liong dalam Herawan (1995) menetapkan koefisien pengaliran untuk atap adalah 0,75 sampai dengan 0,85. Akan tetapi Sunjoto (1995) menetapkan sebesar 0,95 . Dewasa ini, oleh karena sangat bervariasinya jenis bahan penutup atap, maka koefisien pengaliran $c$ pada atap sangat bergantung bada bahan penutupnya. Hasil penelitian mengenai besarnya 
koefisien pengaliran $c$ dari berbagai permukaan adalah seperti tabel berikut:

\section{b. Durasi Hujan.}

Pemberian debit masukan ke dalam media lobang resap biopori memiliki durasi tertentu selama $t$. Apabila media lubang resap biopori sebagai sarana drainase hujan pada areal hunian, biasanya mengambil $t$ berupa waktu hujan yang dominan. Durasi hujan dominan ini diperhitungkan secara empiris berdasarkan rekaman data hujan dari waktu ke waktu. Dalam hal ini Sunjoto (1995) memberikan batasan bahwa maksud dari durasi dominan hujan adalah lamanaya hujan yang paling sering terjadi. Paling akurat datanya adalah yang didapatkan berdasarkan data Automatic Rainfall Recorder (ARR).

Keberadaan durasi $t$ dalam perencanaan media lubang resap biopori akan mempengaruhi besar kecilnya dimensi media lobang resap biopori, terutama mengenai berapa volume tampungan yang dibutuhkan serta kapan kondisi water balance terjadi. Sesungguhnya secara teoritis peranan $t$ memang cukup kecil. Faktor $t$ memberikan peranan yang berarti pada awal proses resap. Akan tetapi jika kondisi keseimbangan telah dicapai pada sistem itu maka rentang waktu selanjutnya tidak memiliki pengaruh.

\section{c. Koefisien Permeabilitas Tanah.}

Sebagai material yang terdiri dari butiran-butiran, maka tanah memiliki ruang pori di dalamnya. Pori-pori di dalam agregat tanah ini memungkinkan dilewati oleh aliran air. Kecepatan aliran air melewati pori-pori tanah ini bergantung pada beberapa faktor seperti angka porositas agregat dan gradien hidrolisnya. Dalam hal ini Cedergren (1989) mengemukakan bahwa koefisien permeabilitas adalah koefisien Darcy yang didefinisikan sebagai kecepatan debit melalui luasan dan gradien hidrolik tertentu. Pada hukum Darcy, untuk aliran laminar pada media porous dinyatakan dalam persamaan :

$$
Q=\text { k.i.A.t }
$$

yang mana

$Q=$ jumlah rembesan melalui penampang tanah

$k=$ koefisien permeabilitas tanah.

$i=$ gradien hidrolik atau beda tinggi aliran air.

$A=$ luas penampang tanah.

$t=$ durasi /rentang waktu.

Selanjutnya dinyatakan ada beberapa hal yang menyebabkan koefisien permeabilitas tanah menjadi bervariasi, di antaranya disebabkan oleh :

- Ukuran dan bentuk butiran tanah.

- Angka pori.

- Suhu.

- Derajat kejenuhan.

Sedangkan Das dalam Noor Endah ( 1998) menambahkan adanya faktor lain seperti kekentalan cairan yang mengalir, distribusi ukuran pori dan kekasaran permukaan butiran tanah. Selain itu pada tanah lempung struktur tanah memegang peranan yang penting sehubungan dengan ketebalan lapisan air yang menempel pada butiran tanah. 
Tabel 1 : Nilai Koefisien Permeabilitas Tanah ( Sumber : Verruijt 1970).

\begin{tabular}{|l|l|l|}
\hline No & Jenis Tanah & Koef.Permeabilitas (m/dt) \\
\hline 1 & Lempung & $<10^{-9}$ \\
2 & Lempung Berpasir & $10^{-9}-10^{-8}$ \\
3 & Lempung Berlanau & $10^{-8}-10^{-7}$ \\
4 & Lanau & $10^{-8}-10^{-7}$ \\
5 & Pasir Sangat Halus & $10^{-6}-10^{-5}$ \\
6 & Pasir Halus & $10^{-5}-10^{-4}$ \\
7 & Pasir Kasar & $10^{-4}-10^{-3}$ \\
8 & Pasir Berkerikil & $10^{-3}-10^{-2}$ \\
9 & Kerikil & $>10^{-2}$ \\
\hline
\end{tabular}

B. Imbuhan Buatan (artificial recharge) . Imbuhan buatan adalah proses peresapan air ke dalam lapisan tanah melalui proses infiltrasi dan atau perkolasi, yang sengaja diciptakan dan dikondisikan oleh manusia. Pengkondisian proses peresapan tersebut dimaksudkan untuk mengganti proses infiltrasi alami yang terganggu, berkurang dan bahkan hilang. Dalam keperluan lain, untuk meningkatkan kapasitas peresapan alami yang ada agar lebih optimal.

Beberapa metode artificial recharge yang dikenal adalah dengan teknik danau buatan, kolam peresapan, parit peresapan, sumur resapan dan lobang resap biopori. Hal tersebut didasari oleh kondisi deposit air tanah yang dari waktu ke waktu mengalami penurunan. Dalam hal ini adanya konversi penggunaan lahan menjadi pemukiman menyebabkan fungsi hidrologis tanah terganggu. Sebagian permukaan lahan menjadi kedap karena tertutup tapak bangunan, jalan, dan pengerasan lainnya. Bagian lahan terbuka juga mengalami proses pemadatan dan biopori berkurang karena berkurangnya tanaman dan fauna tanah sebagai pelaku pembuat biopori di dalam tanah. Hal ini mengakibatkan sebagian besar air hujan tidak lagi meresap ke dalam tanah dan bahkan dibuang melalui saluran drainase. Peningkatan jumlah air hujan yang mengalir di permukaan tanah karena berkurangnya laju peresapan air ke dalam tanah, akan menyebabkan banjir pada musim hujan dan kekeringan pada musim kemarau, serta berkurangnya cadangan air bawah tanah.

\section{Media Lobang Resap Biopori}

Setiap bidang lahan secara alami mempunyai fungsi hidrologis yaitu meresapkan air hujan yang jatuh di permukaan lahan. Air hujan yang meresap kedalam tanah akan menjadi cadangan air di daerah perakaran tanaman (ditahan dalam pori mikro) dan kelebihannya akan bergerak ke bawah melalui pori makro mengisi cadangan air bawah tanah. Fungsi hidrologis ini secara alamiah dapat dipertahankan secara terus menerus karena adanya vegetasi yang tumbuh menutupi permukaan tanah serta aktivitas beraneka ragam biota yang hidup di dalam tanah.

Dibandingkan dengan pori makro di antara agregat tanah, biopori bersifat lebih mantap karena diperkuat oleh senyawa organik, serta tidak mudah menutup karena proses pengembangan tanah akibat pembasahan. Karena dibentuk secara aktif oleh biota tanah maka jumlah biopori akan terus bertambah mengikuti perkembangan akar tanaman serta 
peningkatan populasi dan aktivitas fauna tanah.

Air meresap ke dalam tanah melalui permukaan resapan. Permukaan resapan dapat diperluas dengan membuat lubang secara vertikal ke dalam tanah. Adanya lubang ini, maka permukaan resapan menjadi bertambah karena adanya dinding lubang yang akan dapat meresapkan air ke samping melalui permukaan dinding lubang tersebut. Pada kondisi tanah tertentu, perbandingan antara volume air yang harus meresap melalui permukaan resapan dapat menentukan besarnya laju resapan.

Secara fisik, peningkatan volume air yang masuk melalui permukaan resapan akan menurunkan laju resapan karena meningkatnya beban resapan. Hal ini ditandai dengan lebarnya zone jenuh air di sekitar permukaan resapan yang mengakibatkan laju pergerakan air minimum. Keadaan jenuh air pada lubang yang terlalu lama tidak mendukung berkembangnya keanekaragaman hayati dalam tanah, terutama fauna tanah yang memerlukan oksigen, air, dan makanan yang cukup. Berkurangnya populasi dan aktivitas fauna tanah menyebabkan biopori di dalam tanah berkurang.

Kondisi ini terjadi pada teknologi peresapan air konvensional yang umumnya didesain untuk meresapkan air hujan dengan bidang tampungan yang relatif besar, seperti kolam, dan sumur resapan. Dengan demikian teknologi peresapan air konvensional hanya mengandalkan proses fisik saja, karena proses biologis menjadi terhambat akibat kelebihan air, kekurangan oksigen, dan bahan organik sebagai sumber energi dan unsur hara mereka.

Teknologi lubang resapan biopori (LRB), dikembangkan berdasarkan prinsip menjaga kesehatan ekosistem tanah untuk mendukung adanya keanekaragaman hayati dalam tanah oleh tersedianya cukup air, udara, dan sumber makanan (bahan organik). LRB dibuat dengan menggali lubang kecil ke dalam tanah diameter $10 \mathrm{~cm}$

Fauna tanah akan masuk ke dalam LRB yang berisi sampah organik untuk berlindung dari ancaman pemangsanya. Mereka berkembang biak dan bekerja membuat biopori yang dapat memperlancar peresapan air dan oksigen dalam lubang melalui permukaan resapan yang diperluas oleh adanya dinding LRB. Sampah organik dikunyah, dimakan, dicampur-adukkan dengan mikroba yang secara sinergi dapat mempercepat terjadinya proses pengomposan. Dengan demikian LRB mempunyai kelebihan selain secara fisik dapat mengurangi beban resapan, secara biologis dapat memperbaiki laju peresapan air dan sekaligus dapat mempermudah pemanfaatan sampah organik untuk memperbaiki ekosistem tanah dan mengurangi resiko pencemaran tanah, air, dan udara.

Kumpulan sampah organik yang tidak terlalu besar dalam lubang silindris akan menjadi habitat yang baik bagi fauna tanah terutama cacing tanah yang memerlukan perlindungan dari panas matahari dan kejaran pemangsanya, serta memperoleh makanan, kelembaban dan oksigen yang cukup. Untuk meminimalkan beban lingkungan oleh adanya pengumpulan volume air dan sampah organik di dalam lubang, maka dimensi lubang tidak boleh terlalu besar, atas beberapa pertimbangan teknis seperti:

(1) kemudahan pembuatan dan pemeliharaan lubang,

(2) pengurangan beban resapan,

(3) kemudahan penyebaran guna pengurangan beban lingkungan, dan

(4) kecukupan ketersediaan oksigen bagi fauna tanah;

Lubang resapan sebaiknya berdiameter $10 \mathrm{~cm}$ dengan kedalaman lubang $100 \mathrm{~cm}$ atau tidak melebihi kedalaman air permukaan air bawah tanah. Diameter lubang resapan yang cukup kecil dan terjadinya peningkatan laju peresapan air karena adanya proses pembentukan biopori melalui permukaan resapan, maka teknologi peresapan air demikian diperkenalkan sebagai lubang resapan biopori (LRB)

Manfaat ganda yang diharapkan dengan pembuatan LRB di kawasan pemukiman, antara lain:

1. Meningkatkan laju peresapan air ke dalam tanah. 
2. Memudahkan pemanfaatan sampah organik untuk memperbaiki ekosistem tanah

3. Mengurangi emisi gas-gas rumah kaca $\left(\mathrm{CO}_{2}\right.$ dan Metan).

4. Mengurangi perkembangan penyakit yang dipicu oleh adanya genangan air dan tumpukan sampah organik.

Cara pembuatan LRB dengan bor LRB adalah sebagai berikut.

1. Cara lain dapat mengikuti petunjuk dari alat yang digunakan.

2. Pembuatan LRB diawali dengan penetapan lokasi yang sesuai.

3. Selanjutnya siapkan bor LRB berikut perlengkapan lainnya, seperti seember air berikut gayung, pisau atau sendok semen untuk membersihkan tanah dari bor, sedikit semen, pasir, dan sepotong PVC ukuran 3.5' dan kantong plastik/kertas yang tidak terpakai. untuk mencetak penguat bibir LRB.

4. Bila tanah yang akan dibor dalam kondisi kering maka basahi terlebih dahulu tanah tersebut dengan segayung air.

5. Selanjutnya posisikan mata bor pada permukaan tanah tersebut.

6. Tegakkan tangkai bor secara vertikal dan mulailah memutar stang bor searah jarum jam disertai dengan menekan bor tersebut kedalam tanah.

7. Setelah bor masuk sedalam $20 \mathrm{~cm}$ atau setelah mata bor terlihat penuh dengan tanah, tarik keluar bor tersebut.

8. Pada saat menarik ke atas, bor tetap diputar serah jarum jam. Jangan diputar berlawanan arah, karena dapat menyebabkan tanah terlepas dari mata bor dan jatuh kedalam tanah.

9. Dengan menggunakan pisau atau sepotong kayu/bambu atau sendok semen, bersihkan mata bor sehingga terbebas dari tanah.

10. Lanjutkan kembali pemboran. Setiap kali mata bor penuh terisi tanah, atau setiap kali bor menembus 20 $\mathrm{cm}$, pemboran dihentikan dan mata bor dibersihkan.

11. Begitu seterusnya hingga mencapai kedalaman yang diinginkan, yaitu $100 \mathrm{~cm}$ atau kurang bila permukaan air bawah tanahnya lebih dangkal dari $100 \mathrm{~cm}$.

12. Bila tanah kering sehingga berat pada saat dibor, dianjurkan untuk menyiramnya dengan air terlebih dahulu.

13. Setelah lubang LRB siap, segera lubang tersebut diisi dengan sampah organik. Sedapat mungkin hingga penuh. Bila sampah organik tersebut belum tersedia dalam jumlah memadai untuk memenuhi lubang, sampah sementara cukup disumpalkan saja di bagian teratas lubang sehingga tertutup.

\section{Hasil Penelitian sebelumnya yang Relevan}

1. Pungut (2000), penelitian tentang karakteristik peresapan air hujan pada sumur resapan. Dalam penelitian ini salah satu variable bebasnya adalah dimensi sumur resapan berbentuk langsing, yang dapat mewakili sebagai lobang resapan biopori. Hasil penelitian mengungkapkan bahwa kapasitas resap lobang sumur resapan hasil pengeboran tetap signifikan meskipun hanya memiliki area resap pada dindingnya saja.

2. Pungut (2000), penelitian tentang medan resap sumur resapan. Dalam penelitian ini dibuktikan bahwa lobang resap yang terkonsentrasi pada sebuh titik seperti sumur resapan dan demikian juga pada lobang resap biopori, akan menyebar ke arah samping pada radius tertentu untuk selanjutnya bergravitasi ke bawah sampai menyatu dengan deposit air tanah. Dalam hal ini jarak antar lobang resapan dapat mewakili inputan recharge ke air tanah di bawahnya.

3. Pungut (2006), penelitian tentang sumur galeri di luar tampungan air permukaan sebagai media penjernih. Dalam penelitian ini diungkapkan bahwa lobang disamping tampungan air hujan alam akan terisi melalui proses resap (infiltrasi). Demikian juga pada lobang resapan biopori, maka dapat dipastikan menjadi media infiltrasi terhadap air hujan ke dalam lapisan dalam tanah. 


\section{METODE PENELITIAN}

\section{Variabel Penelitian.}

\section{Variabel Bebas.}

Adapun deskripsi variabel bebas adalah sebagai berikut:
a) Kedalaman lobang resap biopori $=$ $100 \mathrm{~cm}$
b) Diameter pipa biopori $=4$ inchi
c) Jarak antar biopori $=200 \mathrm{~cm}$
d) Luas area terpasang biopori $=800$ $\mathrm{cm} \times 800 \mathrm{~cm}$ atau $5 \times 5$ lobang resap biopori.
e) Isian lobang resap biopori = sampah daun.
f) Lobang sumur control di tengah- tengah areal.

\section{Variabel Terikat.}

Variabel terikat dalam penelitian ini adalah kenaikan level muka air tanah. Dalam hal ini yang dijadikan referensi atau datum adalah garis muka air tanah kondisi steady saat tidak ada hujan yang mempengaruhinya.

\section{Variabel Kontrol.}

Kejadian hujan yang diamati dampaknya pada areal biopori, juga diamati secara bersamaan pada areal tanpa biopori sebagai pembanding.

a) Kondisi dan lokasi areal yang dipasang biopori selokasi dengan areal pembanding tanpa biopori.

b) Lobang sumur kontrol (diameter dan kedalaman) pada 2 areal dibuat sama.

c) Waktu pengukuran muka air tanah dari kejadian hujan dibuat bersamaan antara areal percobaan dan areal control, yaitu antara 10 jam sampai dengan 15 jam setelah kejadian hujan. 


\section{Diagram Alir Penelitian.}

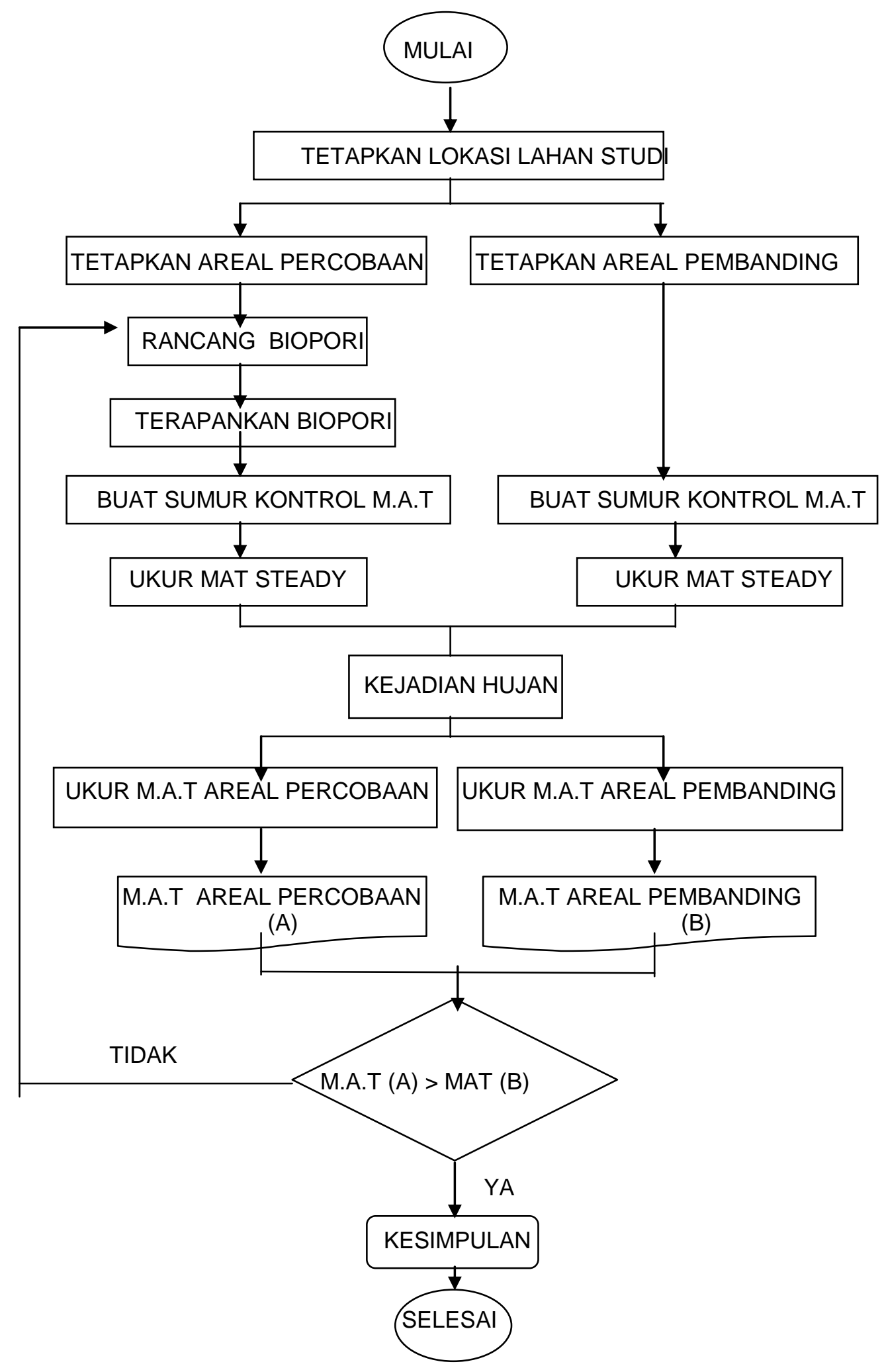

Gambar 1 : Diagram Alir Penelitian 


\section{Waktu dan Tempat Pelaksanaan Percobaan}

a. Waktu Pelaksanaan.

Pelaksanaan penelitian direncanakan pada semester genap 2011/2012, yaitu pada bulan April-Mei 2012.

b. Tempat Pelaksanaan Penelitian.

Tempat pelaksanaan penelitian direncanakan di areal Kampus II Universitas PGRI Adi Buana Surabaya, jl. Dukuh Menanggal XII Surabaya.

\section{B. Pengumpulan Data.}

Data-data yang diperlukan dalam penelitian ini akan dikumpulkan melalui pengamatan terhadap percoban. Adapun data-data yang diperlukan untuk keperluan analisis yaitu:

1. Data elevasi muka air tanah kondisi tidak hujan (Steady).

a. Diukur pada saat tidak ada kejadiaan hujan.

b. Diukur dari muka tanah ke permukaan air tanah pada lobang sumur kontrol.

c. Diukur menggunakan bantuan batang atau benang yang dapat member indikasi batas Muka Air Tanah.
2. Data elevasi muka air tanah kondisi setelah ada kejadian hujan.

a. Diukur setelah terjadi proses infiltrasi air hujan kedalam tanah, dalam penelitian ini ditetapkan antara selang waktu 10 jam sampai 15 jam dari kejadian hujan.

b. Diukur secara berulang (replikasi) sejumlah minimal 3 kali dengan menetapkan kejadian hujan yang berbeda.

c. Diukur pada sumur control areal percobaan, dan pada sumur kontrol areal pembanding.

\section{Analisis Data}

1. Merata-rata elevasi muka air tanah kondisi steady.

2. Merata-rata elevasi muka air tanah kondisi setelah ada kejadian hujan, meliputi muka air tanah pada areal percobaan dan pada areal pembanding.

3. Membandingkan kecepatan kenaikan muka air tanah antara areal percobaan dengan areal pembanding.

4. Mempersentase kenaikan muka air tanah akibat perlakuan biopori pada kondisi yang diperlakukan dalam percobaan.

\section{HASIL PENELITIAN}

\section{Deskripsi Data Hasil Penelitian.}

1. Data muka air tanah tanpa kejadian hujan (kondisi steady)

Tabel 2: Ukuran muka air tanah terhadap muka tanah pada kondisi

Steady di areal percobaan.

\begin{tabular}{|l|l|c|l|}
\hline No & Waktu Pengukuran & $\begin{array}{c}\text { Kedalaman MAT } \\
\text { (dalam cm) }\end{array}$ & Keterangan \\
\hline 1 & 14 April 2012 & 141 & \\
2 & 17 April 2012 & 139 & \\
3 & 18 April 2012 & 139 & \\
\hline & Rerata & 140 & \\
\hline
\end{tabular}



Tanah

Tabel 3: Ukuran muka air tanah terhadap muka tanah pada kondisi

Steady di areal pembanding.

\begin{tabular}{|l|l|c|l|}
\hline No & Waktu Pengukuran & $\begin{array}{r}\text { Kedalaman MAT } \\
(\text { dalam cm) }\end{array}$ & Keterangan \\
\hline 1 & 14 April 2012 & 143 & \\
3 & 17 April 2012 & 138 & \\
\hline & 18 April 2012 & 139 & \\
\hline
\end{tabular}

2. Data muka air tanah setelah kejadian hujan di areal percobaan.

Tabel4 : Ukuran muka air tanah terhadap muka tanah pada kondisi

Setelah ada kejadian hujan di areal percobaan.

\begin{tabular}{|l|l|c|c|}
\hline No & Waktu Pengukuran & $\begin{array}{c}\text { Kedalaman MAT } \\
\text { (dalam cm) }\end{array}$ & $\begin{array}{c}\text { Rentang Waktu } \\
\text { setelah hujan (jam) }\end{array}$ \\
\hline 1 & 14 April 2012 & 136 & 10 \\
2 & 17 April 2012 & 134 & 15 \\
3 & 18 April 2012 & 133 & 14 \\
\hline & Rerata & 134,333 & \\
\hline
\end{tabular}

3. Data muka air tanah setelah kejadian hujan di areal pembanding.

Tabel 5: Ukuran muka air tanah terhadap muka tanah pada kondisi

Setelah ada kejadian hujan di areal pembanding.

\begin{tabular}{|l|l|c|c|}
\hline No & Waktu Pengukuran & $\begin{array}{c}\text { Kedalaman MAT } \\
\text { (dalam cm) }\end{array}$ & $\begin{array}{c}\text { Rentang Waktu } \\
\text { setelah hujan (jam) }\end{array}$ \\
\hline 1 & 14 April 2012 & 141 & 10 \\
2 & 17 April 2012 & 136 & 15 \\
3 & 18 April 2012 & 138 & 14 \\
\hline & Rerata & 138,33 & \\
\hline
\end{tabular}

\section{Analisis Data.}

1. Keberadaan Muka Air Tanah pada Kondisi Steady (tanpa kejadian hujan)

a. Pada areal percobaan (rerata) $=140 \mathrm{~cm}$ dari muka tanah.

b. Pada areal pembanding (rerata) $=141 \mathrm{~cm}$ dari muka tanah.

2. Keberadaan Muka Air Tanah pada Kondisi pada kondisi ada kejadian hujan. 
a. Pada areal percobaan (rerata) $=134,333 \mathrm{~cm}$ dari muka tanah.

b. Pada areal pembanding (rerata) $=138,333 \mathrm{~cm}$ dari muka tanah.

3. Kenaikan Muka Air Tanah akibat kejadian hujan.

a. Pada areal percobaan $($ rerata $)=140 \mathrm{~cm}-134,333 \mathrm{~cm} .=5,667 \mathrm{~cm}$.

b. Pada areal pembanding (rerata) $=141 \mathrm{~cm}-138,333 \mathrm{~cm}=2,667 \mathrm{~cm}$.

4. Persentase kenaikan Muka Air Tanah akibat kejadian hujan.

a. Pada areal percobaan dengan penerapan biopori $=$ $(5,667 \mathrm{~cm} / 140 \mathrm{~cm}) \times 100 \%=4,00 \%$

b. Pada areal pembanding tanpa penerapan biopori $=$ $(2,667 \mathrm{~cm} / 141 \mathrm{~cm}) \times 100 \%=1,90 \%$

\section{Pembahasan.}

1. Faktor-faktor yang mempengaruhi kecepatan infiltrasi air hujan ke dalam tanah hingga menambah elevasi Muka Air Tanah.

Air limpasan hujan yang berada di permukaan bumi jika tidak mengalir ke arah horizontal akan mengalami proses meresap ke dalam bumi yang disebut proses infiltrasi. Infiltrasi melalui lapisan penghalang disebut perkolasi. Baik infiltrasi maupun perkolasi akan menyuplai air tanah (groundwater). Proses infiltrasi dipengaruhi oleh beberapa faktor, di antaranya:

a. Porositas lapisan tanah.

b. Durasi inputan.

c. Debit/volume inputan.

d. Jenis tutupan lahan.

e. Kemiringan (sloope) lahan.

Pada studi ini biopori terbukti mampu mempercepat kenaikan muka air tanah di lapisan dalam tanah, karena biopori mampu memanipulasi faktor porositas tanah dan faktor tutupan lahan. Dalam hal ini melalui lobang-lobang pipa biopori, air lebih disegerakan mengalami proses infiltrasi dibandingkan harus menembus tanah selapis-demi selapis secara alami. Sedangkan dari segi tutupan lahan, air masuk ke dalam tanah lebih mudah ke dalam lobang resap biopori dibandingkan melalui tembus lapisan tutupan vegetasi pada lahan.

2. Faktor-faktor yang tidak teramati dalam penelitian.
Terdapat beberapa faktor yang tidak mampu dikondisikan alam penelitian ini, namun sesungguhnya memiliki peran yang penting dalam menghasilkan data penelitian yang akurat. Faktor-faktor itu ialah:

a. Rentang waktu antara hujan dengan pengamatan seharusnya tepat pada saat proses infiltrasi air hujan yang bersangkutan benar-benar telah selesai dan telah menghasilkan deposit air tanah, sehingga nyata telah sepenuhnya merubah elevasi Muka Air Tanah.

b. Desain fisik biopori perlu dirancang sesuai kondisi porositas lapisan tanah, begitu pula jarak pasangnya.

\section{SIMPULAN DAN SARAN}

\section{Simpulan.}

1. Lobang resap biopori terbukti dapat dijadikan media untuk mengganti proses peresapan air hujan ke dalam lapisan tanah akibat permukaan lahan yang tertutup lapisan kedap, atau untuk membantu laju peresapan infiltrasi yang ingin ditingkatkan kecepatannya.

2. Media lobang resap biopori terbukti mampu menambah deposit air tanah dengan indikasi mampu menaikkan Muka Air Tanah lebih tinggi daripada yang tidak dipasang media biopori .

3. Ada perbedaan kecepatan kenaikan permukaan Muka Air Tanah pada lahan yang diterapkan biopori degan yang tidak diterapkan media biopori, dalam hal ini lahan yang dipasang 
media biopori ukuran 4 inchi sedalam $100 \mathrm{~cm}$ pada jarak pasang $200 \mathrm{~m}$ memiliki kecepatan kenaikan muka air tanah 2 kali lebih besar dibandingkan tanpa dipasang media biopori.

\section{Saran-saran.}

Saran-saran yang diajukan sehubungan dengan hasil penelitian ini ialah:

1. Untuk mengganti lahan yang tutupan vegetasinya dihilangkan, sebaiknya peresapan air hujan ke dalam tanah tetap disediakan alternatif lain diantaranya dengan media lobang resap biopori.

2. Untuk mempercepat laju peresapan air hujan ke dalam lapisan tanah, dapat ditambah dengan menerapkan media biopori pada lahan.

3. Diperlukan penelitian lanjutan terhadap penerapan biopori sebagai media peresap air ke dalam lapisan tanah, dengan menambahkan beberapa variabel yang belum dikaji dalam penelitian ini.

\section{DAFTAR PUSTAKA}

Aboejoewono A. 1995. Penerapan Sumur Resapan dengan Berbagai Aspeknya di Wilayah DKI Jakarta. Prosiding Seminar Pengelolaan dan Pemanfaatan Airtanah 1995 Oleh BPPT, Jakarta. Hal: 173 - 181.

Anonymous, 1997. Drainase Perkotaan. Gunadarma, Jakarta.

Anonymous, Artificial Recharge of Groundwater. http://www.vyh.fi

Anonymous, Tata Cara Perencanaan Umum Drainase Perkotaan., Sistem Informasi Bintek PU. http://www.pu.go.id

Bisri, M. Aliran Air Tanah. Fakultas Teknik Universitas Brawijaya, Malang.

Cedergren, H R. 1988. Seepage, Drainage, and Flow Nets. John Willey and Sons. New York.

Chaidir Anwar M.1995. Resapan Hujan Tanpa Luapan-Model Simulasi Numerik. Prosiding Seminar Pengelolaan dan Pemanfaatan Airtanah 1995 Oleh BPPT, Jakarta. Hal: 208 242.

Das, B. M. 1985. Mekanika Tanah. Alih Bahasa Noor Endah dan Indrasurya BM. 1998. Erlangga, Jakarta.

Herawan, W. dkk, 1995. Teknik Perencanaan Regional Bangunan Peresap dengan Nomograf, Jurnal Penelitian dan Pengembangan Pengairan No.35 Th.10-Kw II 1995, Jakarta. Hal : $34-51$.

Huisman, L. and Olsthoorn TN, 1983. Artificial Groundwater Recharge, Pitman Advanced Publishing Program, Boston

Issoewandhono S. 1995. Volume Tampungan Ekstrem Sumur Resapan Air Hujan Berwawasan Lingkungan pada Hujan Berulang-ulang. Prosiding Seminar Pengelolaan dan Pemanfaatan Airtanah 1995 BPPT, Jakarta. Hal: 298 - 309.

Pungut, 2000. Karakteristik Sistem Drainase Sumur Resapan melalui Uji Model Fisik, Thesis Pascasarjana Universitas Brawijaya, Malang. 
Sunjoto. 1995. Sistem Peresapan Air Hujan Di Kawasan Pesisir. Prosiding Seminar Pengelolaan dan Pemanfaatan Airtanah 1995 BPPT, Jakarta. Hal.: 157 - 172.

Verruijt,A. 1970. Theory of Groundwater Flow. Mcmilland And Co LTD. London.

Wanny Adidarma dkk. 1998. Kajian Hujan dan Resapan Dalam Perhitungan Banjir Rencana. Prosiding PIT HATHI XV 1998, Bandung. Hal: 368 - 377.

GEODe II, Geologic Explorations on Disk, Produced by Tasa Graphics Art Inc, Prentice Hall http://id.wikipedia.org/wiki/Banji__Jakarta_2007

http://www.media-indonesia.com/berita.asp?id=123927

http://www.monitordepok.com/news/berita-utama/12048.html 